\title{
Training Programs for Managing Well-being in Companies
}

RECEIVED: NOVEMBER 2014

REVISED: JUNE 2015

\section{Sonja Treven}

Faculty of Economics and Business, University of Maribor, Slovenia sonja.treven@um.si

\section{Urška Treven}

PaX Stabil GmbH, Gabersdorf, Austria

treven.urska@gmail.com

\section{Simona Šarotar Žižek}

Faculty of Economics and Business, University of Maribor, Slovenia simona.sarotar@um.si

\begin{abstract}
This paper discussed the significance of well-being (WB) and well-being management (WBM). As successful WBM requires the implementation of different training programs, such programs are presented in detail. The cause-effect relationship between training and individual/organizational performance is researched as well. The aim of the research to support this article was to present WBM, its training programs, as well as the determination of WBM activities concerning the mentioned programs implemented in Slovenian organizations.
\end{abstract}

Keywords: Training, well-being, employee diversity, stress

\section{Introduction}

Well-being (WB) is a central motivational goal for many people. It is important for individuals, but it is even more important for employers and organizations. In organizations, all processes need to work in ways that enable employees' WB to be sustained. This means the organizations need to find ways of enabling employees in order to enhance their well-being.

WB plays a key role in delivering most of the important outcomes associated with successful, highly performing organizations. Individuals who feel well have a lot of advantages as leaders, managers and employees (Robertson \& Tinline, 2008). WB is also a platform for low rates of sickness and absence, optimal levels of employee turnover, and high productivity. Furthermore, from a talent management perspective, an organization with a reputation for WB among its employees is also more likely to be able to attract the best from the talent pool of potential employees.

Thus, organizations need effective management of $\mathrm{WB}$, as the positive consequences of WB are evident. An important part of well-being management (WBM) training programs is discussed in this paper, which is the objective in the theoretical part of the article; objectives in the empirical part cover the measurement of WBM activities in Slovenian organizations.
ACCEPTED: JUNE 2015

DOI: 10.1515/ngoe-2015-0015

UDK: 005.32:331.101.32

JEL: M12

\section{NG OE}

NAŠE GOSPODARSTVO OUR ECONOMY

\begin{tabular}{l|l|l} 
Vol. 61 No. 42015 \\
\hline
\end{tabular}

pp. $23-31$ 


\section{Definition of Well-being (WB)}

WB research is especially prominent in the current empirical psychology field and provided the basis for building "positive psychology"-in other words, the movement in psychology that studies the preconditions, conditions, and processes that contribute to the optimal functioning of people, groups, and organizations. Ross Rijavec and Miljković (2006) found that research within positive psychology can be divided into three sections:

- positive subjective experiences

- positive individual characteristics

- $\quad$ positive institutions/organizations

According to Ryan and Deci (2001), the current WB research has been derived from two general perspectives. The first perspective is the hedonic approach, which focuses on happiness and defines WB in terms of pleasure attainment and pain avoidance. In the hedonic tradition, psychologists have concentrated on the assessment of subjective WB, which consists of three elements: (1) life satisfaction; (2) the presence of positive mood; and (3) the absence of negative mood. All this together is summarized as happiness (Ryan \& Deci, 2001). The second perspective is the eudaimonic approach, which focuses on meaning and self-realization and defines WB in terms of the degree to which a person is fully functioning. The eudaimonic perspective assesses how well people live in relation to their true selves (Waterman, 1993). Psychological WB integrates six distinct components of positive psychological functioning.

In combination, these dimensions encompass a breadth of wellness that includes positive evaluations of oneself and one's past life (Self-Acceptance), a sense of continued growth and development as a person (Personal Growth), the belief that one's life is purposeful and meaningful (Purpose in Life), the possession of quality relations with others (Positive Relations With Others), the capacity to manage effectively one's life and surrounding world (Environmental Mastery), and a sense of self-determination (Autonomy). (Ryff \& Keyes, 1995, p. 719)

Ryan and Deci (2001) mentioned that the eudemonic theorists argue that WB and happiness are distinct, for not all sources of pleasure foster WB. They presented the self-determination theory, which posits that there are three basic psychological needs-autonomy, competence, and relatedness - and theorizes that fulfillment of these needs is essential for psychological growth and WB.

These two views have given rise to different research focuses and a basis of knowledge that is in some areas divergent and in others complementary.

\section{Managing Well-being in Work Settings}

WBM in organizations is more important on a day-today basis. As the main goal is to ensure employees' WB, organizations have to manage their human resources well, including functions such as the planning of personnel, development and training, performance evaluation, remuneration, and labor relations, (Potocan, Mulej, \& Nedelko, 2013; Šarotar Žižek, Treven, Mulej, \& Vaner, 2011). A number of writers have stressed the importance of actively manging the human resources of a company (e.g., Beardwell \& Claydon, 2007; Gomez-Meija, Balkin, \& Cardy, 2007). They exposed that human capital has the potential to generate "economic rent” and that employees are an asset, not just a cost.

Employees cannot be healthy and feel well in their work settings if they face stressful situations on a daily basis. Hence, an important part of successful WBM in organizations is also stress management (Andre, 2008; Pettinger, 2002). Stress management, which can be defined as stress prevention, covers many factors with which employees have to cope in their work environment; the related programs include stress management workshops and programs in techniques for relaxation like meditation, yoga, and time management (Treven, Treven, \& Šarotar Žižek, 2011).

Employee diversity management (EDM) in organizations is another part of WBM that integrates (a) an appreciation of differences and (b) the creation of a setting where everyone feels valued and accepted (Treven \& Mulej, 2007). An organization's progress in EDM managers can be monitored via organizational surveys of attitudes and perceptions, among other means. EDM assumes that groups will retain their own characteristics and will shape the company as well as be shaped by it, creating a common set of values that will-namely, strengthening ties with customers, enhancing recruitment, and the like. EDM is sometimes resisted due to a fear of change and discomfort with differences (Schermerhorn, Hunt, \& Osborn, 2004). In order to improve employees' WB, managers can carry out various diversity management programs.

We have already mentioned that organizational training programs can help employees improve their WB through the formation of various training programs that support their WB and prevention of stress. Such programs are presented in the next chapter.

\section{Training Programs for Managing Well-being}

Preparing special training programs for managing WB in organizations can help employees develop self-respect and 
feel well and valued in their work settings, without regard to their culture, religion, ethnicity, gender, age, disability, or other individual differences. The most often applied programs for managing the employees' well-being include the following:

- $\quad$ Stress management programs

- Diversity management programs

- Wellness programs

- Employee assistance programs

- Programs for personal growth

\subsection{Stress management programs}

The intention of stress management programs is to teach the individual how to reduce stress in his or her life effectively. Such programs might include various workshops in order to introduce employees to topics of stress and stress management. Such workshops can give the employees general knowledge about the causes of stress, its consequences, and stress management methods; alternatively, they can be oriented to the training of employees in a particular method, such as yoga, meditation, and breathing and relaxation techniques.

\section{General stress management workshop}

Employees who attend general stress management workshops benefit in many ways. First, they are acquainted with the nature of stress and how humans respond physically and psychologically to stressful situations. Second, employees are informed about the specific stressors and symptoms that cause to them the most difficulty in their lives and work settings. Third, they are educated about the possible consequences of stress.

Stress has its origins in the demands of organizational and personal life. The stress response occurs as a result of the individual's interaction and reaction to the stressor (Davis, McKay, \& Robbins Eshelman, 2000). Several responses to the demands faced can be observed. The behavioral response to the demand is the set of specific observable actions taken in response to the demand. In addition to the behavioral response, the individual will have a psychological response that takes the form of cognitive and emotional reactions. Employees can be influenced by specific stressors and symptoms related to the organization or job as well as factors relating to other aspects of their lives. Therefore, we can distinguish between work-related causes of stress and causes of stress from outside of work.

Employees who attend general stress management workshops are educated about the possible consequences of stress as well. Stress causes a variety of different health problems, including medical (heart disease and stroke, backache and arthritis, ulcers, etc.), behavioral (smoking, drug and alcohol abuse, violence, etc.) and psychological problems (family conflict, sleep disturbance, sexual dysfunction, depression, etc.).

\section{Relaxation training}

Relaxation is a form of meditation and a state of concentration. By using the mind to focus upon an object, image, or thought, one cancels out the distraction associated with everyday life. The relaxation response has been shown to counter-balance the stress response (Šarotar Žižek, Treven, \& Mulej, 2015).

Training programs in techniques for relaxation can include various workshops in order to acquaint employees with particular techniques, like meditation, yoga, deep breathing, and progressive muscle relaxation, or teach them to use relaxation techniques sequentially. Such workshops can give the employees general knowledge about relaxation, together with instructions for applying specific relaxation techniques. General information about relaxation can include the four basic elements of the relaxation response, information about what employees will experience during relaxation, and information about the effects after relaxation. In addition, workshops in relaxation techniques can provide instructions on how to apply the specific relaxation technique.

\subsection{Diversity management programs}

Diversity management programs can be divided into two categories: awareness-based diversity training and skill-based diversity training. The aim of these programs is to make interactions between diverse groups of people easier and more effective. When employees pay attention to each other, the road to the improvement of productivity based on employees' creative energies is provided (Treven \& Mulej, 2007).

Diversity training helps managers understand and value individual differences and develop strong diagnostic skills. The dissemination of factual information might change some beliefs, but more emotion-oriented persuasive techniques and long-term educational efforts might be needed to alter them (Greenberg \& Baron, 2000).

\section{Awareness-based diversity training}

Specifically, awareness-based diversity training is designed to raise people's awareness of diversity issues in the workplace and to help them recognize the underlying assumptions they make about people. It is a very basic orientation-and 
one that takes a cognitive approach. It usually involves teaching people about the business necessity of valuing diversity, making them sensitive to their own cultural assumptions and biases. This can involve various experiential exercises as well as real-life case studies that help people view others as individuals, not stereotyped members of groups.

\section{Skill-based diversity training}

Skill-based diversity training builds on the awareness approach to develop people's skills in managing diversity. As such, it goes beyond raising awareness to develop the tools needed to interact effectively with others. Four main tools are involved in this process:

- Cross-cultural understanding: Understanding the cultural differences responsible for different co-workers' behaviors on the job (Klarič, 2005).

- Intercultural communication: Learning to overcome verbal and nonverbal barriers to communication across cultures.

- Facilitation skills: Training in helping others to alleviate misunderstandings that might result from cultural differences.

- Flexibility and adaptability: Cultivating the ability to patiently take new and different approaches when dealing with others who are different.

\subsection{Wellness programs}

Wellness programs have been developed in organizations to help employees (including managers) maintain their physical and mental health. A healthy employee can manage stress more easily than one suffering from phobias, nightmares, a lack of appetite, heart disease, or other health troubles (Treven et al., 2011). Such programs consist of workshops that train employees to use some stress-reducing behaviors, such as losing weight, exercising, and giving up smoking. Although organizations provide the relevant know-how, the individual employees are responsible for controlling their own lives. Organizations that implement wellness programs for their employees consider such programs a sensible investment that generate positive organizational and financial effects. The employees able to manage stress effectively enjoy better health and achieve well-being, which in turn means a reduced absence from work because of illness and greater productivity.

\subsection{Employee assistance programs}

Employee assistance programs support employees facing many kinds of problems, such as family problems, problems raising children, moving into a new residence, career planning, and financial and legal advice. Such programs have been in use for quite some years in the United States and is also increasing in the European Union and Slovenia (Hellriegel \& Slocum, 2004; Treven et al., 2011).

\subsection{Programs for personal growth}

Personal growth includes the growth of an individual's personal traits - a combination of personal characteristics, values, inclinations, motives, attitudes, and interests that, along with one's skills, knowledge and work results, environment, and willpower, create a requisitely holistic person. Such an individual is the result of psycho-sociological and economic-material influences, factors, and experiences acquired from being active in one's family as well as his/ her educational and social environments. What follows is the presentation of the four key personal growth programs (Šarotar Žižek, 2012).

\section{Programs for a positive mindset}

Positive mental attitude purifies the intellect and brings about experiences of wisdom (Čertalič, 1998). Keller (2001) defined the concept of positive mental attitude as mental glasses through which an individual observes the world around him/her. Some people observe the world through rose-tinted spectacles; others through the dimmed ones. The former are characterized by a positive attitude while the latter by negative ones. The first one usually thinks "I can" and the other "I cannot."

\section{Programs for focusing on the present moment}

The present moment is the moment when a person resides or simply: is. An awareness of the present moment is rather an exception than a norm, as thoughts can often take people back to their past (how they have been hurt by others, what failure they have experienced, how they have been cheated, etc.) or their future (what position to achieve, what material assets to purchase, what status to obtain). An individual should be thinking of both the future and the past in a limited way and only when necessary.

\section{Programs for the control of thoughts and feelings}

A theory of emotional intelligence developed in the 1990s by Salovey and Mayer (summarized in Goleman, 2001) refers to the capacity to control one's own emotions and feelings and the ability to listen to the feelings that guide human thought and action. Possible interventions aimed to increase 
emotional intelligence can be found in the workplace. Many such programs are already known and established as trainings, such as those fostering better relations between people, increased motivation, stress management, and conflict resolution (Salovey, Mayer, \& Caruso, 2002).

\section{Programs for achieving higher levels of awareness}

An individual can achieve spiritual maturity through the implementation of techniques for spiritual growth, such as meditation, yoga, logo therapy, and practical Buddhist principles to achieve balance. An important factor in raising awareness is meditation, in which the focus moves from rational thought through irrational or intuitive thinking to transcendental contemplation. To achieve higher levels of awareness, it is also important to strengthen spiritual intelligence (Zohar \& Marshall, 2004).

\section{Cause-effect relationship between training and individual/organizational performance}

Managers would likely agree that employees make a critical difference when it comes to innovation, organizational performance, competitiveness, and-ultimately-business success. Yet what can organizations do to attract and keep creative, dedicated, and thriving employees who make organizations flourish? What working conditions motivate employees to be engaged, give their best, go the extra mile, and persist in the face of difficulties? Modern organizations focus on the management of human capital, not the traditional organizational structures that heavily rely on management control and economic principles of cost reduction, efficiency, and cash flow (Bakker \& Schaufeli, 2008).

Becker and Gerhart (1996) described why human resource management (HRM) decisions are likely to have important and unique influences on organizational performance. Delaney and Huselid (1996) also mentioned that progressive HRM practices, including selectivity in staffing, training, and incentive compensation, are positively related to the perceptual measures of organizational performance.

WB is quite applicable to business. As managers and employees focus on satisfying their basic human needs in the workplace, clarifying the desired outcomes and increasing opportunities for individual fulfillment and growth can help them increase opportunities for the success of their organization (Harter, Schmidt, \& Keyes, 2006). Thus, a theoretical framework to describe why this might occur is provided. Data from Harter and coauthors (2006) indicate that workplaces with engaged employees do a better job, on average, of keeping employees and satisfying customers; hence, they are more productive and profitable. Therefore, WB in the workplace and performance are not independent, but rather complementary and interdependent components of a financially and psychologically healthy workplace.

Wright and Cropanzano (2000) researched the happy-productive worker and hypothesis that job satisfaction doesn't impact only on performance but also on employee’s well-being.

On these bases, the applied research was conducted.

\section{Empirical Research}

\subsection{Methodology}

\section{Hypothesis development}

The central research question is whether Slovenian organizations conduct programs to manage employees' WB. Our hypothesis is: Slovenian organizations provide above-average value in their programs for managing employees' well-being.

\section{Measuring instrument}

A quantitative (structured survey) research method was deemed appropriate to allow for the calculation of the actual measures of the tested concepts. We developed and validated a measurement instrument that ultimately consisted of 22 Likert-type questions measuring WB programs in organizations, which are a part of HRM.

\section{Procedure}

This research was a part of the project entitled "A requisitely holistic model of measuring employees’ well-being in transitional organizations as compared with both innovative and less innovative ones," a research project created for the Public Agency of the Republic of Slovenia for Research Activity. We collected data on HRM in organizations in Slovenia from April 1, 2011, until June 20, 2011. We also measured WB programs as an important part of HRM in organizations.

\section{Data collection and participants}

In the third phase, a computer-assisted web interview was used to collect data from 2409 randomly selected organizations from all organizations with more than 10 employees in 
Slovenia. Only organizations with more than 10 employees were chosen as we assumed that those with fewer employees have not developed HRM efforts. The population of companies was determined from the database of the Agency of the Republic of Slovenia for Public Legal Records and Related Services. First, as the main informants, CEOs or members of the board of directors responsible for HRM were identified in each organization and then contacted by phone. Informants were provided with the web link to the questionnaire and asked to complete it. A total of 320 usable responses were obtained from the managers, representing a response rate of $13.3 \%$.

Table 1. Descriptive Statistics of Respondents

\begin{tabular}{|c|c|}
\hline Type of market & Frequency \\
\hline Mainly providing end-customer services & 67 \\
\hline Mainly providing B2B services & 108 \\
\hline Manly providing end-customer products & 40 \\
\hline Mainly providing B2B products & 101 \\
\hline Missing & 4 \\
\hline Total & 320 \\
\hline \multicolumn{2}{|l|}{ Size } \\
\hline Large & 23 \\
\hline Medium & 74 \\
\hline Small & 221 \\
\hline Missing & 2 \\
\hline Total & 320 \\
\hline \multicolumn{2}{|l|}{ Industry } \\
\hline Manufacturing & 79 \\
\hline Real estate, renting and business activities & 20 \\
\hline Construction & 50 \\
\hline $\begin{array}{l}\text { Other community, social and personal service } \\
\text { activities }\end{array}$ & 12 \\
\hline Wholesale and retail trade & 77 \\
\hline Hotels and restaurants & 6 \\
\hline Transport, storage and communication & 16 \\
\hline Missing & 60 \\
\hline Total & 320 \\
\hline \multicolumn{2}{|l|}{ Title of the respondent } \\
\hline CEO & 148 \\
\hline Board member & 21 \\
\hline$\underline{\text { Executive director }}$ & 14 \\
\hline Director/Head of HRM department & 26 \\
\hline Director/Head of general department & 37 \\
\hline Did not want to answer & 74 \\
\hline Total & 320 \\
\hline
\end{tabular}

\subsection{Research results}

Below we present results of the examination of HRM activities that organizations perform to ensure WB and that are part of previously mentioned training programs.

Table 2 presents HRM activities that organizations offer to raise employees' WB. The indicator with the highest mean is "We ensure technical security of workplace and process." High means (over 4) were also achieved by "We ensure that employees understand their duties and responsibilities," "We care for good relations and good organizational climate," and "We ensure economic security of the workplace." The lowest mean occurred for "Within working hours we organize aerobic exercises.”

The highest dispersion of responses (standard deviation), meaning respondents differ most on this factor, was for "We care about babysitting for employees' children." The lowest value of standard deviation was for: "We provide technical security of workplace and process."

Positive values of asymmetry coefficient have nine indicators. The highest value is shown by the indicator "Within working hours we organize aerobic exercises" and the lowest one by "We create opportunities for older adults to maintain participation and engagement within the organization.”

All other indicators have negative values of asymmetry coefficient; their asymmetric distributions are shown along the left side of the table. The indicator "We provide technical security of workplace and process" has the highest negative value of asymmetry coefficient whereas the highest positive value is for "Within working hours we organize aerobic exercises.”

Negative values of the kurtosis coefficient are found for seven indicators. The highest value belongs to the item "We have established intergenerational cooperation" and the lowest negative value to the item "We offer employees flexible working hours and the appropriate distribution of work." Thus, the distribution of these indicators is flattened, while the other indicators are characterized by a tapered distribution. The indicator "We provide technical security of workplace and process" has the thorniest distribution while the flattest one belongs to "We have established intergenerational cooperation.”

An analysis of the HRM activity to provide WB showed that organizations that are above average in providing technical security for the workplace and process as well as caring that employees understand their duties and responsibilities are perceived as well-being organizations. In 
addition the indicators "We take care of a good relationship and a good working environment," "We ensure economic security of workplace," "We care for the good communication and flow of information within the organization," "We offer employees free days and rest days," and "Work and processes are organized to minimize uncertainty” exceed the average value of 4.30. Organizations are also above average in providing the necessary training to employees who work well and are satisfied to receive the necessary assistance. The same applies to the possibility of reconciliation of work and family life, flexible working hours, and adequate allocation of work as well as career development.

Table 2. Descriptive Statistics of HRM Activities Concerning Well-being Management

\begin{tabular}{|c|c|c|c|c|c|c|c|c|}
\hline & \multirow{2}{*}{$\mathrm{N}$} & \multirow{2}{*}{ Mean } & \multirow{2}{*}{ Median } & \multirow{2}{*}{$\begin{array}{l}\text { Standard } \\
\text { deviation }\end{array}$} & \multicolumn{2}{|c|}{ Skewness } & \multicolumn{2}{|c|}{ Kurtosis } \\
\hline & & & & & Statist. & Std. error & Statist. & Std. error \\
\hline $\begin{array}{l}\text { We ensure technical security of workplace and } \\
\text { process. }\end{array}$ & 318 & 4,64 & 5,00 & 0,633 & $-2,251$ & 0,137 & 7,145 & 0,273 \\
\hline $\begin{array}{l}\text { We ensure that employees understand their duties } \\
\text { and responsibilities. }\end{array}$ & 317 & 4,46 & 5,00 & 0,638 & $-0,917$ & 0,137 & 0,464 & 0,273 \\
\hline $\begin{array}{l}\text { We take care of good relationships and a good } \\
\text { working environment. }\end{array}$ & 317 & 4,44 & 5,00 & 0,716 & $-1,405$ & 0,137 & 2,808 & 0,273 \\
\hline We ensure economic security of workplace. & 317 & 4,41 & 5,00 & 0,744 & $-1,385$ & 0,137 & 2,544 & 0,273 \\
\hline $\begin{array}{l}\text { We ensure good communication and flow of } \\
\text { information within the organization. }\end{array}$ & 316 & 4,39 & 4,50 & 0,728 & $-1,338$ & 0,137 & 2,724 & 0,273 \\
\hline We offer to employees free days and rest days. & 317 & 4,34 & 5,00 & 0,867 & $-1,285$ & 0,137 & 1,331 & 0,273 \\
\hline $\begin{array}{l}\text { Work and processes are organized in such a way } \\
\text { that the uncertainty is as small as possible. }\end{array}$ & 316 & 4,32 & 4,00 & 0,744 & $-1,052$ & 0,137 & 1,340 & 0,273 \\
\hline $\begin{array}{l}\text { We offer employees the necessary training to work } \\
\text { well and satisfied. }\end{array}$ & 317 & 4,23 & 4,00 & 0,860 & $-0,936$ & 0,137 & 0,432 & 0,273 \\
\hline $\begin{array}{l}\text { In case of problems, we offer necessary help } \\
\text { (financial, psychological, legal advice, assistance } \\
\text { with relocation, etc.). }\end{array}$ & 318 & 4,03 & 4,00 & 0,987 & $-0,962$ & 0,137 & 0,713 & 0,273 \\
\hline $\begin{array}{l}\text { We offer the possibility of reconciling work and } \\
\text { family life. }\end{array}$ & 318 & 4,00 & 4,00 & 0,938 & $-0,675$ & 0,137 & $-0,118$ & 0,273 \\
\hline $\begin{array}{l}\text { We offer to employees flexible working hours and } \\
\text { appropriate distribution of work. }\end{array}$ & 318 & 3,93 & 4,00 & 1,071 & $-0,798$ & 0,137 & $-0,014$ & 0,273 \\
\hline We assist employees in career development. & 318 & 3,91 & 4,00 & 0,993 & $-0,751$ & 0,137 & 0,226 & 0,273 \\
\hline We have established intergenerational cooperation. & 313 & 2,88 & 3,00 & 1,392 & $-0,013$ & 0,138 & $-1,245$ & 0,275 \\
\hline $\begin{array}{l}\text { We create opportunities for older adults to } \\
\text { maintain participation and engagement within the } \\
\text { organization. }\end{array}$ & 316 & 2,38 & 2,00 & 1,357 & 0,512 & 0,137 & $-1,024$ & 0,273 \\
\hline We care about babysitting for employees' children. & 317 & 2,33 & 2,00 & 1,475 & 0,640 & 0,137 & $-1,059$ & 0,273 \\
\hline $\begin{array}{l}\text { We care about physical performance of employees } \\
\text { by hiring a gym, fitness center, or other forms of a } \\
\text { regular weekly recreation. }\end{array}$ & 316 & 2,12 & 2,00 & 1,369 & 0,927 & 0,137 & $-0,435$ & 0,273 \\
\hline $\begin{array}{l}\text { We organize training about healthy ways of living } \\
\text { (workshops on healthy eating, smoking cessation, } \\
\text { the importance of physical activity, etc.). }\end{array}$ & 316 & 1,96 & 2,00 & 1,192 & 1,116 & 0,137 & 0,217 & 0,273 \\
\hline We co-finance employees' recreation. & 314 & 1,92 & 1,00 & 1,322 & 1,199 & 0,138 & 0,105 & 0,274 \\
\hline $\begin{array}{l}\text { We have implemented programs to increase } \\
\text { happiness of employees (employees learn to take } \\
\text { over properties of happy people). }\end{array}$ & 317 & 1,64 & 1,00 & 1,023 & 1,633 & 0,137 & 2,049 & 0,273 \\
\hline We co-finance employees' wellness services. & 317 & 1,47 & 1,00 & 0,946 & 2,284 & 0,137 & 4,828 & 0,273 \\
\hline We organize aerobic exercise within working hours. & 316 & 1,35 & 1,00 & 0,781 & 2,461 & 0,137 & 5,975 & 0,273 \\
\hline Valid & 296 & & & & & & & \\
\hline
\end{tabular}

Measured on Likert scale: 1 = never, 5 = always

Source: Authors. 
The responding organizations were shown to be below average in the following WBM items:

- Creating opportunities for older adults to maintain participation and engagement within the organization

- Care about babysitting for employees

- Organizing training about methods for stress relief

- Caring for the physical performance of employees by hiring a gym, fitness center, or other forms of regular weekly recreation

- Co-financing of recreation to employees

- Establishing a program to increase happiness of employees

- Financing wellness services

- $\quad$ Organizing aerobic services within working hours

\section{Concluding Remarks}

Training is an important function of HRM and, as such, it is strongly connected with other functions, like planning staff, recruiting and selection, and rewards. Given the strong need for successful WBM in enterprises, training that contributes to achieving that aim is of the utmost significance. In this paper, some WBM training programs, such as stress management programs, diversity management programs, wellness programs, employee assistance programs, and programs for personal growth, were thus presented. Some results from our research were also presented in order to demonstrate the connection between training and individual/organizational performance and highlight conditions for checking the hypothesis that Slovenian organizations provide above-average value in programs managing employees' well-being. We confirmed this as 13 of 22 activities showed a higher value than average.

Future research should measure the efficiency of WBM training and its impact on the organization's performance.

\section{References}

1. Andre, R. (2008). Organizational behavior. New York: Pearson Education.

2. Bakker, A. B., \& Schaufeli, W. B. (2008). Positive organizational behavior: Engaged employees in flourishing organizations. Journal of Organizational Behavior, 29, 147-154. http://dx.doi.org/10.1002/job.515

3. Beardwell, J., \& Claydon, T. (2007). Human resource management. Harlow: Prentice Hall.

4. Becker, B., \& Gerhart, B. (1996). The impact of human resource management on organizational performance: Progress and prospects. Academy of Management Journal, 39(4), 779-801. http://dx.doi.org/10.2307/256712

5. Čertalič, V. (1998). Joga uma in telesa (Yoga of mind and body). Ljubljana: Mladinska knjiga.

6. Davis, M., McKay, M., \& Robbins Eshelman, E. (2000). The relaxation and stress reduction workbook. Oakland, CA: New Harbinger Publications Inc.

7. Delaney, J. T., \& Huselid, M. A. (1996). The impact of human resource management practices on perceptions of organizational performance. Academy of Management Journal, 39(4), 949-969. http://dx.doi.org/10.2307/256718

8. Goleman, D. (2001). Čustvena inteligenca na delovnem mestu (The emotionally intelligent workplace). Ljubljana: Mladinska knjiga.

9. Gomez-Meija L. R., Balkin D. B., \& Cardy, R. L. (2007). Managing human resources. New York: Pearson.

10. Greenberg, J., \& Baron, R.A. (2000). Behavior in organizations. New Jersey: Prentice Hall International.

11. Harter, J. K., Schmidt, F. L., \& Keyes, C. L. M. (2003). Well-being in the workplace and its relationship to business outcomes: A review of the Gallup studies. In C. L. M. Keyes \& J. Haidt (Eds.), Flourishing: The positive person and the life well lived (pp. 205-224). Washington, DC: American Psychological Association. http://dx.doi.org/10.1037/10594-009

12. Hellriegel, D., \& Slocum, J. W., Jr. (2004). Organizational behavior. Mason, OH: Thomson South-Western.

13. Keller, J. (2001). Miselna naravnanost je vse. Ljubljana: Lisac \& Lisac.

14. Klarič, Š. (2005). Skrb za izseljene managerje v procesu kulturne prilagoditve (Unpublished M.A. thesis). University of Maribor, Faculty of Economics and Business, Maribor.

15. Pettinger, R. (2002). Stress management. Oxford: Capstone Publishing (A Wiley Company).

16. Potocan, V., Mulej, M., \& Nedelko, Z. (2013). The influence of employees' ethical behavior on enterprises social responsibility. Systemic practice and action research, 26(6), 497-511 http://dx.doi.org/10.1007/s11213-013-9299-3

17. Robertson, I., \& Tinline, D. (2008). Understanding and improving psychological well-being for individual and organisational effectiveness. In A. Kinder, R. Hughes, \& C. L. Cooper (Eds.) Employee well-being support (pp. 39-51). Chicester: John Wiley \& Sons Ltd. http://dx.doi.org/10.1002/9780470773246.ch3

18. Ross Rijavec, M., \& Miljković, D. (2006). Pozitivna psihologija: Psihologija čije vrijeme (ponovno) došlo. Društvena istraživanja, 15(4-5; 84-85), 621-641.

19. Ryan, R. M., \& Deci, E. L. (2001). On happiness and human potentials: A review of research on hedonic and eudaimonic well-being. Annual Review of Psychology, 52, 141-166. http://dx.doi.org/10.1146/annurev.psych.52.1.141

20. Ryff, C. D., \& Keyes, C. L. M. (1995). The structure of psychological well-being revisited. Journal of Personality and Social Psychology, 69, 719-727. http://dx.doi.org/10.1037/0022-3514.69.4.719 
21. Salovey, P., Mayer, J. D., \& Caruso, D. (2002). The positive psychology of emotional intelligence. Handbook of positive psychology. Oxford: Oxford University Press.

22. Schermerhorn, Jr., J. R., Hunt, J. G., \& Osborn, R. N. (2004). Core concepts of organizational behavior. Hoboken, NJ: Wiley.

23. Šarotar Žižek, S., Treven, S., Mulej, M., \& Vaner, M. (2011). The integrative and innovative model of HRM in Slovenian tourism. Academica turistica, 4(2), 33-49.

24. Šarotar Žižek, S. (2012) Vpliv psihičnega dobrega počutja na temelju zadostne in potrebne osebne celovitosti zaposlenega na uspešnost organizacije (Influence of psychical well-being on success of organization on a basis of requisite personal holism of an employee, in Slovene only) (Unpublished doctoral dissertation). University of Maribor, Faculty of Economics and Business, Maribor.

25. Šarotar Žižek, S., Treven, S., \& Mulej, M. (2015). The conceptual model of well-being management based on achieving requisite personal holism. Cybernetics and Systems, forthcoming. http://dx.doi.org/10.1080/01969722.2015.1012379

26. Treven, S., \& Mulej, M. (2007). The systemic approach to the encouragement of innovativeness through employee diversity management. Kybernetes, 36(2), 144-156. http://dx.doi.org/10.1108/03684920710741198

27. Treven, U., Treven, S., \& Šarotar Žižek, S. (2011). Effective approaches to managing stress of employees. Review of Management Innovation and Creativity, 4(10), 46-57.

28. Waterman, A. S. (1993). Two conceptions of happiness: Contrasts of personal expressiveness (eudaimonia) and hedonic enjoyment. Journal of Personality and Social Psychology, 64, 678-691. http://dx.doi.org/10.1037/0022-3514.64.4.678

29. Wright, T. A., \& Cropanzano, R. (2000). Psychological well-being and job satisfaction as predictors of job performance. Journal of Occupational Health Psychology, 5(1), 84-94. http://dx.doi.org/10.1037/1076-8998.5.1.84

30. Zohar, D., \& Marshall, I. (2004). Duhovna inteligenca. Tržič: Učila International.

\section{Authors}

Sonja Treven, Ph.D., is a professor in the field of human resource management at the School of Business and Economics at the University of Maribor in Slovenia. She is the head of the Department of Management and Organization and of the Institute of Organization and Information Systems. She is the author/co-author of 13 books as well as more than 80 scientific articles. She has participated in more than 100 domestic and international conferences with her papers as an author or co-author.

Mag. Urška Treven, law graduate, is employed in the international company PaX Stabil in Austria in the field of marketing. Since 2006, she has gained extensive experience in the field of justice, international projects, and the field of international cooperation with customers as well as the field of scientific research. She has actively participated in many national and international conferences and has co-authored one book and several international scientific articles.

Simona Šarotar Žižek, Ph.D., is an assistant professor at the University of Maribor's Faculty of Economic and Business. She is the author and/or co-author of several articles published in various international and Slovenian journals and/or presented at scientific and expert conferences. She has prepared several scientific monographs and chapters in scientific and expert monographs. On several occasions she has been invited to present her papers at scientific and expert conferences. She is also active in preparing and implementing projects.

\section{Programi usposabljanja za zagotavljanje dobrega počutja $v$ podjetjih}

\section{Izvleček}

V prispevku najprej osvetljujemo pomen dobrega počutja (WB), nato pa izpostavljamo menedžment dobrega počutja (WBM). Uspešen WBM zahteva izvajanje različnih programov usposabljanja, zato te programe predstavljamo še podrobneje. Raziskujemo tudi vzročno-posledični odnos med usposabljanjem in uspešnostjo posameznikov/organizacije. Namen raziskave, na kateri temelji prispevek, je zato bil: predstaviti WBM in programe usposabljanja zanj ter strinjanje z izvajanjem dejavnosti navedenih programov v slovenskih organizacijah.

Ključne besede: usposabljanje, dobro počutje, raznolikost zaposlenih, stres 